\title{
The location choice of transnational operation of Yunnan enterprises
}

\author{
Wen Zhang* \\ International Business School \\ Yunnan University of Finance and Economics \\ Kunming, China \\ zhangxiaowen615@163.com \\ Hong Yi \\ International Business School \\ Kunming, China \\ ynyihong@126.com
}

\author{
Yu Liu \\ International Business School \\ Yunnan University of Finance and Economics \\ Kunming, China \\ liuyu_913@outlook.com \\ Yue Yang \\ International Business School \\ Yunnan University of Finance and Economics \\ Kunming, China \\ 532630837@qq.com
}

\begin{abstract}
Along with the "One Belt And One Road" carrying out in a deep-going way. Yunnan enterprises will get a new opportunity for international business because of its unique geographical location, in which occupy a central position. This article analyzes the status and characteristics of transnational business in Yunnan, and find out the problem of Yunnan enterprises in the location selection. Finally, it will put forward the corresponding solutions in order to improve the international competitiveness of enterprises in Yunnan.
\end{abstract}

Keywords-Yunnan enterprises; Transnational operation; location choice

\section{INTRODUCTION}

The Chinese government is striving to promote the implementation of the "going out" strategy, it directly affects the international status of our country in the economic globalization .In order to realize the external economic strategy, it should be reflected in the formulation and practice of transnational business strategy of the enterprises. Yunnan Province, as the core member of the southwest economic circle, is an important bridge and channel for China to connect the two major economic circles of ASEAN and the Southwest, which has great influence on the Southeast Asian countries [1]. Yunnan is adjacent to Southeast Asia and is abundant of resources, so it can seize comparative advantages and potential advantages, make full use of the strategic advantage of "One Belt, One Road," "BCIM Economic Corridor", "Greater Mekong Subregion", make Yunnan enterprises and products to the international markets in a step-by-step and focused manner.

Although foreign scholars on the growth and development of multi-national corporation is relatively rich, but research on the factors affecting the location selection of multi-national corporation is few. Pain found that the main reason for attracting foreign direct investment into a certain region is the production cost advantage of the region [2]. Sabi believed that the multi-national corporation was willing to invest in the host

\footnotetext{
* Corresponding author
}

country with great market potential in order to gain a long-term profit [3]. Root and Ahmed showed that size of a market was more significant than the GDP value data to the FDI location selection [4]. Domestic scholars also make depth study on the transnational operation problem. Kuang Jinyun thought that transnational management referred to the enterprise make enhance the core competitiveness of enterprises as a goal, do business activities including import and export trade, attract foreign investment, foreign investment and international marketing, and all business activities[5]. Lu Minghong, Pan Zhen showed that the size of the market was one of important factors that affect the location choice of direct investment [6]; Li Xia thought that the development stage of Yunnan Province determined the choice of foreign investment enterprises was mainly countries in international direct investment in the first stage and the second order section. Vietnam, India, Bangladesh, Burma, Thailand, Indonesia, Laos and Cambodia was the first choice of foreign investment in Yunnan Province [7].

\section{The SituAtion OF REgional Distribution OF TRANSNATIONAL MANAGEMENT OF YUNNAN ENTERPRISES}

\section{A. The general situation of the location distribution of transnational management of enterprises in Yunnan}

As of the end of 2015, the number of enterprises (institutions) abroad of Yunnan Province has reached 635, the actual total overseas investment amounted to 57.6 dollars. Among them, the number of the newly established foreign enterprises of Yunnan Province is 103, foreign direct investment up to 1.344 billion dollars, rose by $30.4 \%$ year-onyear, the achievement of foreign direct investment in the country ranked fourteenth in China, and the third in the western region. In 2015, Yunnan Province, signed totally 95 new contracts of contracted projects with foreign countries, the new contracts amount of 1286.38 million dollars, and if finished 2341.62 million dollars, ranking seventeenth in China. In 2015, Yunnan Province sent a total amount of 10398 labor personnel abroad, of which, 7348 people under the project, accounting for 
$70.67 \% ; 775$ people under the labor cooperation, accounting for $7.45 \% ; 2275$ people under overseas investment, accounting for $21.88 \%$. The proportion of high-end labor service personnel is $6.8 \%$.

Foreign investment industry of Yunnan Province appears pluralistic gradually, the fields of investment are expanding. By 2015, the total foreign investment of Yunnan Province distributed in nine categories of the national economic category. From the investment point of view, investment in the traditional areas of agriculture, mining, and electric power is still dominant. But the investment industry has appeared pluralistic. For example, newly approved investment companies continue to expand the field of high-end manufacturing such as pharmaceutical manufacturing, new services such as ecological protection and environmental governance industry, e-commerce services, cultural industries and so on. In addition, the number of cross-border mergers and acquisitions business of Yunnan Province last year reaches to 7 Chinese investment amount reach to 870 million, and it are at a record high.

\section{B. Yunnan enterprises' transnational business location is too concentrated}

Foreign direct investment of Yunnan enterprises in the global distribution is relatively in wide range, but the region is relatively concentrated. In 2014, the total trade volume between Yunnan and ASEAN is 14.314 billion dollars, an increase of $31.5 \%$, accounting for $48.3 \%$ of the total trade volume of the whole province; of which, the volume of export is 8.73 billion dollars, an increase of $29.4 \%$; the volume of import is 5.59 billion dollars, an increase of $34.9 \%$. Over the same period, the total amount of the province's border trade amounted to 3.579 billion dollars, an increase of $6.8 \%$, accounting for $12.1 \%$ of the province's total trade volume, and accounting for $25 \%$ of the ASEAN trade volume. Among them, the volume of export is 2.179 billion dollars, an increase of $18 \%$; the volume of import is 1.4 billion dollars, a decrease of $5.9 \%$. The countries of the Greater Mekong Subregion (Laos, Myanmar, Thailand, Cambodia, Vietnam) are the main markets of Yunnan enterprises. In 2015, Yunnan enterprises set up new business investment in Laos, Myanmar, Thailand at amount of 67 , accounting for $65 \%$ of Yunnan's new established enterprises overseas. The actual investment is 793 million dollars, accounting for $59.4 \%$ of the total actual investment over the same period.

At the same time, Yunnan enterprises invest most of the funds to neighboring countries in areas of electric power, energy, mineral resources development, logging, agriculture and other industry whose ecological environment is easy to destroy. Meanwhile, the investment to electric power and mineral resources accounts for more than $80 \%$ of the total investment. This kind of distribution is too concentrated, obviously it cannot adapt to the changes in the international economic environment and the implementation of market diversification strategy requirements. One problem is that it will bring up repeat construction and self-competition. The excessive competition of the enterprises in the same province will damage the interests of our enterprises, and also damages the international image of Yunnan enterprises. Another problem is that the excessive concentration of investment location is not conducive to the diversification of investment risk. Overseas investment is vulnerable to the danger of wiping out.

\section{Most investment in primary industry}

Overall, Yunnan enterprises make most investment to the primary industry. Transnational operation of enterprises in Yunnan take more attention on primary products and laborintensive industry investment, lay particular stress on investment to consumer goods, energy industry, and service industry. It relatively neglect investment to new and high technology industry. In the structure of the projects, foreign investment enterprises of Yunnan province engaged in planting and other agricultural production reach to 208, accounting for $68.5 \%$ of the total number of foreign investment enterprises of Yunnan. Moreover, the number of enterprises engaged in mineral development is 21 , accounting for $6.9 \%$ of the total number of foreign investment enterprises in Yunnan. Enterprises engaged in engineering services reach to18, accounting for $18.6 \%$ of the total number of foreign investment enterprises. Visibly, Yunnan enterprises' foreign investment mainly engaged in agriculture, mining and other first industries, accounting for $75 \%$ of the total number of foreign investment enterprises. This is mainly due to that Yunnan's enterprises overseas lack of technical advantages, capital, innovation capability, which greatly restricts the improvement of the international competitiveness of foreign enterprises of Yunnan.

In 2014, the trade volume of Yunnan Province on Burma Jade reaches to 2.094 billion dollars, of which export is 1.076 billion dollars, an increase of $198.9 \%$, related enterprises of jade processing and import and export of general trade contributed about 1.24 billion dollars, accounted for $36.15 \%$ of the total trade volume in ASEAN.

In 2014, Yunnan Province exports a total of 50.82 million dollars of coke. The export market is Burma, Laos and Vietnam. Exports to Vietnam accounted for $98.5 \%$ in total trade volume. Yunnan exports to ASEAN 393 million dollars of phosphorus chemical products and 160 million dollars of electricity power and 375 million dollars of agricultural products. All in all, Yunnan's current foreign investment structure is still in the primary stage, the industrial structure needs to be upgraded.

\section{AdVANTAgES OF TRANSNATIONAL OPERATION OF YUNNAN ENTERPRISES}

\section{A. Location advantage}

Yunnan Province is an inland frontier province (autonomous region), which has the most bordering countries, channels and the best natural conditions for trading. Yunnan Province can southwards to Hanoi and Bangkok, Singapore and Rangoon directly through Trans-Asian Railway, in the west through Burma directly to Bangladesh and arrive in the Indian Ocean, then through the South Asian subcontinent to connect the Middle East. There are 23 ports in Yunnan province, which has the geographical advantages of construction of export commodity production base to Southeast 
Asia, advantages of ports and base of entrepot trade, and advantages of regional comprehensive bonded zone. These location characteristics make Yunnan enterprises into the neighboring countries at lower cost. As shown in Table 1-1, as of the end of 2014, Yunnan Province trade most closely with the following ten countries and regions: Myanmar, Hong Kong, the United States, Vietnam, Laos, Indonesia, Malaysia, Thailand, South Korea, Indonesia. Among these countries, there are nine countries in Asia Pacific region, and enterprises of Yunnan Province developing multinational business and foreign direct investment activities also focus on such countries and regions. One of the most important reasons is that Yunnan Province have strong complementarity with its neighboring countries in economy and are close in culture. Regional advantages make the higher degree of trade between Yunnan and these countries, but also more conducive to the development of transnational business activities.

TABLE I. THE TOP 10 COUNTRIES OR REGIONS IMPORT AND EXPORT WITH YUNNAN (DEADLINE: 2014)

\begin{tabular}{|c|c|c|}
\hline Ranking & Countries and regions & $\begin{array}{c}\text { Total net exports (USD } \\
100 \text { million) }\end{array}$ \\
\hline 1 & Myanmar & 70.47 \\
\hline 2 & Hong Kong & 32.87 \\
\hline 3 & U.S.A & 18.14 \\
\hline 4 & Vietnam & 15.62 \\
\hline 5 & Laos & 13.72 \\
\hline 6 & Indonesia & 13 \\
\hline 7 & Malaysia & 12.48 \\
\hline 8 & Thailand & 10.73 \\
\hline 9 & Korea & 9.46 \\
\hline 10 & Singapore & 5.50 \\
\hline
\end{tabular}

Source: Statistical Almanac of Yunnan Province, 2015

\section{B. Resource advantage}

Yunnan has large amount of mineral resources and is known as The Kingdom of Nonferrous metal. Reserves of phosphate rock resources ranks NO.1 among China, 10 kinds of nonferrous metals output ranks No. 3 among the country. Yunnan province has be proved that it reserves 24 billion tons of the energy and mineral resources, ranks No. 9 in China. As 30 thousand kinds of higher plants in the country, Yunnan province accounts for more than $60 \%$. Yunnan rational development of biological resources is effectively carried out, tobacco, rubber, tea, medicinal herbs, tropical fruit and other industries have a considerable development, flowers, coffee, spices and other industries are rising. Yunnan's energy resources is extremely rich, especially the hydropower resources, 225.6 billion cubic meters of the province's total amount of water resources, hydropower resources reserves up to 104 million kilowatts, can be developed installed capacity about 90 million kilowatts, ranking second in the country. In addition, Yunnan's solar energy, thermal energy, wind energy, geothermal utilization prospects are very impressive. Visibly, Yunnan province has an important resource advantage, which will become an important guarantee for enterprises to go out of Yunnan province.

\section{Strategic advantage}

"One Belt, One Road" was put forward, the advantages of BCIM Economic Corridor, Chinese ASEAN Free Trade Area is extended, and the Greater Mekong Subregion is in-depth cooperation. All these will bring a comprehensive strategic advantage for Yunnan. The construction of the Silk Road Economic Belt and the 21st century Maritime Silk Road and Border Economic Cooperation Zone, cross-border economic cooperation zone construction and many open policy superimposed together gradually, the strategic position of Yunnan in the regional development will gradually become prominent. Yunnan will speed up the construction of open platform, enhance the level and influence of ASEAN Expo, Kunming Trade Fair, Travel Fair, and promote construction of the Red River Comprehensive Bonded Zone, Lincang Border Economic Cooperation and Mohan Border Economic Cooperation Zone, fully accelerate the Airport Economic Zone, Export Processing Zone, Inter-Provincial Economic Cooperation Zones. Yunnan will explore construction of border free trade area, and promote the development of the open economy to achieve new results, to accelerate the development of enterprises in Yunnan Province to go out to other countries and regions.

\section{COUNTERMEASURE}

\section{A. Developing countries in the Asia Pacific region is the preferred location of the multinational operation of Yunnan enterprises.}

At this stage, enterprises of Yunnan should pay attention to Asian developing countries, it will be more conducive to realize their advantage, to achieve the maximum efficiency. For specific analysis, on the one hand, developing countries, as the host country, with its limitations of their own conditions, their demand for foreign investment is relatively strong. They will set the lower threshold, so the enterprises of Yunnan are able to achieve advantages of their great market demand and potential development. Yunnan can effectively transfer the saturation of the domestic market through the enterprises' transnational management. On the other hand, the Asian countries, especially Southeast Asian countries, have many similarities of humanities environment with Yunnan, which makes the folk psychological distance closer, more favorable to carry out international business activities. Therefore, Yunnan enterprises should make dialectical and comprehensive choice of treatment of enterprise transnational business location. 


\section{B. The United States, Japan and other developed countries are the strategic location of Yunnan enterprises transnational business}

The United States, Japan and other developed countries, their enterprises in the development of transnational business started earlier, and thus accumulated a wealth of technical conditions and have a strong financial strength. For other countries, it's hard to go into these countries, because the country's internal market competition is fierce enough, and the people of these countries are at the highest level of product requirements, the technical content of the product requirements are more demanding. However, the future development trend of Yunnan enterprises is still go into such developed countries. Firstly, the developed countries provide more massive and more spending power of the market for Yunnan's enterprises, and it has complete infrastructure. Secondly, industries in developed countries has more high technology content, and it's difficult for foreign enterprises to achieve their high technology and patents, so for enterprises of Yunnan Province, the most effective way is by way of transnational operation, to achieve enterprise grasp of developed countries which has high technology and management experience, to realize the input output utility maximization. In addition to the transnational mergers and acquisitions, Yunnan enterprises can gain technical resources and human resources of the host country through Greenfield investments.

\section{CONCLUSION}

The paper analyses the distribution status of Yunnan enterprises' location choice of transnational operation and find that the location choice of transnational operation of enterprises of Yunnan are mostly neighboring countries in Southeast Asia, whether to invest and build factories or overseas project contracting. The main reason is Yunnan next to Southeast Asia, having a greater similarity with the humanistic environment of the region. Yunnan enterprises carrying out transnational business activities is of low cost and high convenience. At the same time, current foreign investment structure of Yunnan
Province is still in the primary stage, the industrial structure needs to be upgraded. Therefore, enterprises of Yunnan should take the Asia Pacific region in the first place, and also attach importance to the strategic position of the United States, Japan and other developed countries, to speed up the pace of technological progress, improve the level of management, so as to realize the rapid development of the transnational operation of enterprises of Yunnan.

\section{ACKNOWLEDGEMENT}

As I finished this paper, I am really willing to give my sincere gratitude to those who have kept giving me so much help. First, I would like to thank my supervisor Professor Yi Hong with all my heart. Without his constant encouragement and guidance, I would not finish this paper. Second, my good wishes to all the teachers in International Business School, they have given me professional knowledge. Third, my special thanks to my classmates and my friends who have prepared to give me a hand whenever I need.

\section{REFERENCES}

[1] L. H, "The model selection of Yunnan enterprises to enter the GMS market," Yunnan University of Finance and Economics, 2013.

[2] Ray Barrell, and Nigel Pain, "Trade restraints and Japanese direct investment flows," European Economic Review, 1998, pp. 431-431.

[3] Sabi, M, "An application of the theory of foreign direct investment to multinational banking in LDC's," Journal of International Business Studies, vol. 3, 1988.

[4] Root, F.\&A. Ahmed, "Empirical determinants of manufacturing foreign direct investment in developing countries," Economic Development and Cultural Change, 1979, pp. 4-4.

[5] G.Y. Kuang, "Research on transnational operation of enterprises in Yunnan,” Inquiry into Economic Issues, vol.9, 2006, pp. 118-120.

[6] M.H. Lu and Z. Pan, "Evaluation and comparison of investment environment in various regions of China: $1990 \sim 2000$," Management World, vol. 11, 2002, pp. 42-49

[7] X. Li, "The location choice of transnational operation of Yunnan enterprises," Journal of Yunnan University of Finance and Economics, vol. S1, 2007, pp. 167-170. 